\title{
Antihyperglycemic, Vasodilator, and Diuretic Activities of Microencapsulated Bioactive Product from Moringa stenopetala Leaves Extract
}

\author{
Debebe Worku Dadi $\left(\mathbb{D},{ }^{1}\right.$ Shimelis Admassu Emire, ${ }^{2}$ Asfaw Debella Hagos, ${ }^{3}$ Frehiwot Teka, ${ }^{3}$ \\ Samuel Woldekidan, ${ }^{3}$ Abiy Abebe, ${ }^{3}$ and Meron Sileshi ${ }^{3}$ \\ ${ }^{1}$ Department of Food Engineering and Postharvest Technology, Institute of Technology, Ambo University, P.O. Box 19, Ambo, \\ Ethiopia \\ ${ }^{2}$ School of Chemical and Bioengineering, Institute of Technology, Addis Ababa University, P.O. Box 385, Addis Ababa, Ethiopia \\ ${ }^{3}$ Traditional and Modern Medicine Research Directorate, Ethiopia Public Health Institute, P.O. Box 1242, Addis Ababa, Ethiopia
}

Correspondence should be addressed to Debebe Worku Dadi; debeworku2010@gmail.com

Received 25 June 2020; Revised 29 July 2020; Accepted 5 August 2020; Published 14 August 2020

Academic Editor: quancai sun

Copyright $\odot 2020$ Debebe Worku Dadi et al. This is an open access article distributed under the Creative Commons Attribution License, which permits unrestricted use, distribution, and reproduction in any medium, provided the original work is properly cited.

\begin{abstract}
Moringa stenopetala has nutritional and medicinal values, which is widely used by the local communities. The study aimed to evaluate the antihyperglycemic, vasodilator, and diuretic activities of the microencapsulated bioactive product from M. stenopetala leaves extract. Microencapsulation of the extract was done by spray drying technique using maltodextrin and pectin as coating materials with the core: coating ratio of $1: 6$. Then, the antihyperglycemic, diuretic, and vasodilator activities were evaluated after the product was administered to experimental animals at different doses and compared with the control groups. There were no observed physical, behavioral, and physiological changes on the mice during the acute toxicity test. The results also indicated no toxicity signs and death occurrence in the experimental animals up to $5000 \mathrm{mg} / \mathrm{kg}$ administered dose. Therefore, microencapsulated M. stenopetala leaves extract does not produce adverse effects in experimental mice. The study also showed that the microencapsulated bioactive product exhibited significant antihyperglycemic, vasodilator, and diuretic activities as the doses increase. Therefore, the study showed that microencapsulated bioactive product has significant medicinal values. Further detailed studies are recommended on chronic toxicity tests and to understand the possible mechanism of actions on the antihyperglycemic, vasodilator, and diuretic activities of the microencapsulated product.
\end{abstract}

\section{Introduction}

Moringa stenopetala plant has biologically active compounds that have beneficial medicinal attributes in addition to food sources and feed. Traditional treatment using different plant extracts is undertaken for many diseases and health disorders, in particular, in the developing countries [1]. This is due to the presence of various pharmacological active compounds in the plants. About thirty percent of the marketed drugs contain compounds derived from the plants [2]. Although there are many modern antihypertensive medicines, many peoples prefer to use traditional medicines
[3]. M. stenopetala is a plant that has medicinal and nutritional importance for the community and reported to have antihypertensive effects [4] and antidiabetic activity $[5,6]$. Similarly, moringa extract also showed hepato- and kidney protective effects due to its protective action against lipid peroxidation and reactive oxygen species [7]. Furthermore, the toxicity and the medicinal values of the $M$. stenopetala leaves extract have been evaluated using experiments in animal models. The toxicity test of the extract was declared as it does not show toxic signs $[2,8]$.

Phenolic and flavonoid compounds are the major constituents reported from aqueous and alcoholic extracts of 
M. stenopetala leaves [9,10]. These constituents exhibit higher antioxidant activity and are claimed to be responsible for a number of biological activities [11-13]. However, these bioactive constituents are significantly reduced during plant material processing $[14,15]$ and storage [16]. Encapsulation of medicinal plant extracts can be considered as an option to improve the stability of bioactive compounds during processing and storage. Microencapsulation is a technology for packaging of extracts and thereof active ingredients in microparticle matrices [17]. The wall material forms a physical barrier between the active compounds and the external environment and controls the release of the active compounds [18]. Furthermore, it masks the bitter taste and odor of active extracts or compounds [17]. Considering the medicinal importance of $M$. stenopetala, the leaves extract was formulated into microencapsulate using spray drying technology. This study, therefore, aimed to evaluate the antihyperglycemic, diuretic, and vasodilator activities of the microencapsulated product of the extract of $M$. stenopetala leaves.

\section{Materials and Methods}

2.1. Chemicals and Reagents. All chemicals and reagents were of analytical grades. Maltodextrin (Eisse Food Co. Ltd., Korea), high methoxyl pectin (RS-400, Danisco Inc., USA), glacial acetic acid (Labort Fine Chemicals, India), glibenclamide (Remedica, Cyprus), ethanol (WINLAB, UK), D-glucose anhydrous and sodium hydrogen carbonate (Eurostar Scientific Ltd., Liverpool, UK), streptozotocin and potassium phosphate monobasic (Sigma Aldrich, St. Louis, USA), potassium chloride (Park Scientific Ltd., Northampton, UK), calcium chloride (Allied Chemical, New Jersey, USA), magnesium chloride (lot no. 86F-3524, Sigma Chemical Company, St. Louis, USA), magnesium sulfate (BDH Lab Chem Division, UK), sodium chloride (Riedel-de Haen, Germany), and furosemide (ERIS Pharma, Australia) were used in the study.

2.2. Microencapsulated Product Development. The coating material solutions were prepared according to the method described by Dadi et al. [19]. Spray-dried microencapsulated product of $M$. stenopetala leaves extract was developed using maltodextrin (9\%) and pectin (1\%) as a composite coating material with a core: coating ratio of $1: 6$ and an inlet air temperature of the spray dryer at $140^{\circ} \mathrm{C}$. The product was then packed in the aluminum package to protect it from environmental contacts and stored in the refrigerator at $4{ }^{\circ} \mathrm{C}$ until it is used for the experiment.

2.3. Experimental Animal Preparation. The experimental animals were bred at the Ethiopian Public Health Institute. All animals were used under controlled laboratory conditions of temperature $\left(22 \pm 2^{\circ} \mathrm{C}\right)$, humidity, and $12 \mathrm{~h}$ day and $12 \mathrm{~h}$ night and had free access to a standard pellet diet and water ad libitum. The institutional ethical review board ethically approved the studies. The animals were treated throughout the study period according to the guideline for the use and care of animals [20].

2.4. Acute Toxicity Test. The experiment was performed on adult, healthy female Swiss albino mice with a weight range of 25-30 g. The acute toxicity of microencapsulated product from $M$. stenopetala leaves extract was evaluated as follows: the mice were divided into seven groups and five mice were allocated in each group per cage. The animals had fastened for $4-5 \mathrm{~h}$ before taking the initial weight measurement. The administration was done orally with single doses of the microencapsulated product which was dissolved in distilled water at different doses (500, 1000, 1500, 2000, and $5000 \mathrm{mg} /$ $\mathrm{kg}$ ) for five treatment groups and two control groups (coating material for the first group and distilled water for the second group).

2.5. In Vivo Antihyperglycemic Test. Diabetic induction of the mice was done according to the method described by Furman [21]. Briefly, before inducing the streptozotocin (STZ), the animals fasted for $4 \mathrm{~h}$ for which only water was provided as normal. Then, a single-dose STZ solution was freshly prepared in citrate buffer $(\mathrm{pH}=4.5)$ at a concentration of $200 \mathrm{mg} / \mathrm{kg}$ of the body weight of the mice. The STZ solution was induced using intraperitoneal (IP) injection. Five days after STZ injection, the animals were fastened for $6 \mathrm{~h}$ and the blood was taken from the tail vein to measure the glucose level using glucometer (Prodigy, OK Biotech, Hsinchu, Taiwan). Then, the mice were considered as diabetic when their blood glucose level was read as $>150 \mathrm{mg} / \mathrm{dl}$. The antihyperglycemic mice were grouped into six groups, and five mice were put in each cage. The microencapsulated product and the standard drug (glibenclamide) were administered orally using gavage. Groups 1, 2, and 3 were considered as treatment groups which were administered the microencapsulates at the dose of 500,750 , and $1000 \mathrm{mg} / \mathrm{kg}$, respectively. Group 4 was administered the standard drug, glibenclamide, at the dose of $5 \mathrm{mg} / \mathrm{kg}$ which was considered as a positive control group. Group 5 was considered as a negative control group in which diabetic mice stayed without treatment. Group 6 was administered distilled water $(0.5 \mathrm{~mL} / 100 \mathrm{~g})$ which was considered as a normal control group. The administration was done for 21 days. The body weight and the fastened blood glucose level were measured on the 1st, 7 th, 14th, and 21st days.

2.6. In Vitro Vasodilator Activity Test. The in vitro vasodilatory activity of the microencapsulated product of $M$. stenopetala leaves extract was done using isolated guinea pig thoracic aorta according to the methods described by Vogel [22]. The guinea pig was sacrificed by gentle cervical dislocation and the thoracic cavity was opened to identify the aorta. The descending thoracic aorta was then taken and placed in Krebs physiological solution maintained at $37^{\circ} \mathrm{C}$. Excess adherent fat and connective tissues were trimmed off and cleaned. The aorta was cut spirally using a heparinized capillary tube with plastic sealing and a strip of about $2 \mathrm{~mm}$ 
wide and $4 \mathrm{~cm}$ long using a heparinized capillary tube with plastic sealing. The strip was immediately mounted in an organ bath containing $30 \mathrm{~mL}$ Krebs-Henseleit physiological solution. The strip was attached to isometric transducers connected to a polygraph and a resting tension of $1 \mathrm{~g}$ was applied to strip. The aorta ring was mounted under this resting tension onto two $\mathrm{L}$ shaped stainless steel wire hooks gently inserted into the lumen to avoid damage to the endothelium in Krebs-Henseleit solution and allowed to stabilize for about an hour before commencing an experiment. The physiological solution was allowed to pass through a warm water jacket to maintain its temperature and continuous aeration with carbogen $\left(95 \% \mathrm{O}_{2}+5 \% \quad \mathrm{CO}_{2}\right.$ gas mixture) at a $\mathrm{pH}$ of 7.4. The $\mathrm{pH}$ of the buffer was checked every 60 minutes of aeration with carbogen.

After the aortic strip equilibration period of $1 \mathrm{~h}$ under a resting tension of $1 \mathrm{~g}$, tissue viability was confirmed by adding $80 \mathrm{mM} \mathrm{KCl}$. After equilibration and tissue viability was checked, contraction of the thoracic aorta strip was induced by the addition of $80 \mathrm{mM} \mathrm{KCl}$ into the organ bath during which period it was washed by overflowing every $15 \mathrm{~min}$. Once a contraction plateau was achieved, microencapsulated product was administered cumulatively every $15 \mathrm{~min}$ to assess their capacity of reducing thoracic aorta strip contraction induced, and tension responses of the tissue were recorded isometrically with Grass transducers and displayed on a Grass model 7 polygraph. At the end of the experiment, the percent relaxation was determined before and after extract administration. Relaxation, a measure of inhibition of contraction in aorta ring precontracted with a contracting agent, was measured in percentage and calculated using

$$
\% \text { relaxation }\left(R_{\max }\right)=\frac{T_{c}-T_{t}}{T_{c}} * 100,
$$

where $T_{c}$ stands for tension in Newton due to contracting agents, while $T_{t}$ stands for change in tension in Newton after adding encapsulates at different dose level.

2.7. In Vivo Diuretic Activity Test. The diuretic activity of the microencapsulated product was evaluated according to the method described by Vogel [22]. The Wisteria male rats with the body weight in the range of 204-254 g were taken and acclimatized for 7 days. They were kept in the cage with free access to water and standard feed in pellet form. The rats were grouped into five groups; within each cage, six rats were put. Group 1 is a positive control group which was provided furosemide standard drug, group two is negative control group which was provided a saline solution, and the rest three groups were treatment groups in which different doses $(500,750$, and $1000 \mathrm{mg} / \mathrm{kg})$ of the microencapsulated products of $M$. stenopetala leaves extract were provided. The rats were fastened overnight prior to administration. The sample and the standard drug were dissolved in $0.9 \%$ saline solution in the form of $5 \mathrm{~mL} / \mathrm{kg}$ of the rat's weight. Then, a normal saline solution ( $50 \mathrm{~mL} / \mathrm{kg}$ of the rat's weight) was provided for all rats and kept in the metabolic cage for $8 \mathrm{~h}$. All the administration was done orally using gavage. Then, the urine volume was measured every $2 \mathrm{~h}$. Finally, the electrolyte concentration in the urine was measured and analyzed.

The urine output, urinary excretion, diuretic index, diuretic activity, natriuretic activity, saluretic activity, carbonic anhydrase inhibition, $\mathrm{Na}^{+}, \mathrm{K}^{+}$, and $\mathrm{Cl}^{-}$excretion were the parameters determined in order to compare the effects of the test doses of the extract with furosemide on diuresis. The percent of the urinary excretion was calculated as the total urinary output divided by total liquid administered (equation (2)). The ratio of urinary excretion in the test group to urinary excretion in the control group was used as a measure of the diuretic action of the diuretics (equation (3)). The diuretic activity was calculated as the ratio of the diuretic action of the test substances to that of the standard drug (equation (4)):

$\operatorname{urinary}$ excretion $(\%)=\frac{\text { total urine output }(\mathrm{ml})}{\text { total liquid administered }(\mathrm{ml})} * 100$,

$$
\text { diuretic index }=\frac{\text { urinary excretion of treated group }(\mathrm{ml})}{\text { urinary excretion of control group }(\mathrm{ml})} \text {, }
$$

$$
\text { diuretic activity }=\frac{\text { diuretic excretion test } \operatorname{drug}(\mathrm{ml})}{\text { diuretic action of standard drug }(\mathrm{ml})} \text {. }
$$

2.8. Determination of Ion Concentrations in the Excreted Urine. Urinary $\mathrm{Na}^{+}, \mathrm{K}^{+}$, and $\mathrm{Cl}^{-}$ions concentrations of the animals (experimental, positive control, and normal control groups) were measured using ion-selective electrodes (ISE) analysis (AVL 9180 Electrolyte Analyzer, Roche, Germany). Dilutions of the urine samples were made as required to bring electrolyte content in the range that can be determined by the electrolyte analyzer.

2.9. Statistical Data Analysis. All the experimental values were expressed as mean \pm standard deviation. The results were analyzed using analysis of variance (ANOVA) by JMP software (Version 13.0, 2016, SAS Institute Inc., Cary, NC, USA). Tukey's HSD test was used and the difference was considered at a significance level of $P<0.05$.

\section{Results and Discussion}

3.1. Acute Toxicity. The result of the acute toxicity of microencapsulated product from $M$. stenopetala leaves extract indicated that there was no death within 24 hours up to maximum doses (5000 $\mathrm{mg} / \mathrm{kg}$ body weight). In addition, there was no sign of behavioral and physical changes and also body weight reduction within 14 days. Besides, there were no gross pathological changes in color and size. These overall parameters show that the microencapsulated bioactive product of $M$. stenopetala leaves did not show any visible sign of toxicity. Similar results were found for 
TABLE 1: Effects of the microencapsulated bioactive product of $M$. stenopetala on the body weight of the mice.

\begin{tabular}{lcccc}
\hline \multirow{2}{*}{ Treatment groups } & \multicolumn{3}{c}{ Fastened body weight of the mice $(\mathrm{g})$} \\
& 1 st day & 7 th day & 14 th day & $21 \mathrm{st}$ day \\
\hline Dose $500 \mathrm{mg} / \mathrm{kg}$ & $30.03 \pm 4.16^{\mathrm{aA}}$ & $31.12 \pm 4.37^{\mathrm{aAB}}$ & $32.84 \pm 4.90^{\mathrm{aAB}}$ & $33.56 \pm 4.92^{\mathrm{aAB}}$ \\
Dose $750 \mathrm{mg} / \mathrm{kg}$ & $32.92 \pm 3.02^{\mathrm{aA}}$ & $32.40 \pm 3.40^{\mathrm{aAB}}$ & $33.01 \pm 3.43^{\mathrm{aAB}}$ & $33.12 \pm 3.77^{\mathrm{aB}}$ \\
Dose $1000 \mathrm{mg} / \mathrm{kg}$ & $33.84 \pm 3.07^{\mathrm{aA}}$ & $33.56 \pm 3.75^{\mathrm{aAB}}$ & $32.48 \pm 2.76^{\mathrm{aAB}}$ & $33.08 \pm 2.96^{\mathrm{aB}}$ \\
Positive control & $30.57 \pm 2.65^{\mathrm{aA}}$ & $31.04 \pm 1.89^{\mathrm{aAB}}$ & $31.66 \pm 2.36^{\mathrm{aAB}}$ & $32.06 \pm 2.03^{\mathrm{aBC}}$ \\
Negative control & $29.88 \pm 1.71^{\mathrm{aA}}$ & $28.49 \pm 1.09^{\mathrm{abB}}$ & $27.34 \pm 1.03^{\mathrm{bcB}}$ & $26.58 \pm 1.72^{\mathrm{cC}}$ \\
Normal control & $34.08 \pm 3.99^{\mathrm{aA}}$ & $36.10 \pm 4.10^{\mathrm{aA}}$ & $37.74 \pm 3.53^{\mathrm{aA}}$ & $39.76 \pm 3.46^{\mathrm{aA}}$ \\
\hline
\end{tabular}

Superscript letters with small letters indicate the presence of significant differences $(P<0.05)$ in a raw (in different days), whereas the capital letters indicate the presence of significant differences in a column (different doses of the microencapsulates and control groups).

TABle 2: Antihyperglycemic effects of microencapsulated bioactive product of $M$. stenopetala leaves extract.

\begin{tabular}{lcccc}
\hline \multirow{2}{*}{ Treatment groups } & \multicolumn{3}{c}{ Fastened blood glucose level $(\mathrm{mg} / \mathrm{dl})$} \\
& 1 st day & 7 th day & 14 th day & $21 \mathrm{st}$ day \\
\hline Dose $500 \mathrm{mg} / \mathrm{kg}$ & $337.60 \pm 63.93^{\mathrm{aA}}$ & $329.90 \pm 65.33^{\mathrm{aB}}$ & $319.90 \pm 68.30^{\mathrm{aB}}$ & $281.80 \pm 67.05^{\mathrm{aB}}$ \\
Dose $750 \mathrm{mg} / \mathrm{kg}$ & $271.10 \pm 35.86^{\mathrm{aA}}$ & $257.40 \pm 37.60^{\mathrm{aAB}}$ & $241.60 \pm 37.32^{\mathrm{aAB}}$ & $228.20 \pm 33.80^{\mathrm{aAB}}$ \\
Dose $1000 \mathrm{mg} / \mathrm{kg}$ & $300.20 \pm 47.94^{\mathrm{aA}}$ & $263.60 \pm 29.50^{\mathrm{aAB}}$ & $258.90 \pm 48.17^{\mathrm{aA}}$ & $242.00 \pm 47.41^{\mathrm{aAB}}$ \\
Positive control & $291.90 \pm 51.95^{\mathrm{aA}}$ & $265.70 \pm 51.07^{\mathrm{aA}}$ & $248.00 \pm 49.03^{\mathrm{aA}}$ & $221.70 \pm 48.08^{\mathrm{aA}}$ \\
Negative control & $223.90 \pm 37.59^{\mathrm{b}}$ & $316.20 \pm 31.68^{\mathrm{a}}$ & $330.70 \pm 24.11^{\mathrm{a}}$ & $347.10 \pm 36.06^{\mathrm{a}}$ \\
Normal control & $99.00 \pm 5.70^{\mathrm{a}}$ & $99.20 \pm 6.72^{\mathrm{aC}}$ & $98.20 \pm 5.54^{\mathrm{aC}}$ & $98.20 \pm 5.81^{\mathrm{a}}$ \\
\hline
\end{tabular}

Superscript letters with small letters indicate the presence of significant differences $(P<0.05)$ in a raw (in different days), whereas the capital letters indicate the presence of significant differences in a column (different doses of the microencapsulates and control groups).

unencapsulated aqueous and ethanol extracts of $M$. stenopetala leaves $[2,5,6]$. Therefore, the result indicates that the processing conditions and coating materials employed (maltodextrin and pectin) are safe.

3.2. Body Weight. The body weight of the mice had shown significant differences depending on the treatment type. The change in body weight was higher in the normal control group, in which the hyperglycemic mice followed were treated by the glibenclamide and microencapsulated products of low and middle dose levels (Table 1). The change in body weight of microencapsulated product might be attributed to the presence of the antioxidant activity, which may scavenge the free radicals produced by STZ. King [23] stated that STZ is a source of free radicals, which damage the DNA and cause cell destruction. Moreover, the microencapsulate of $M$. stenopetala leaves extract also has nutritional components due to the presence of macro- and micronutrients, which might be used as food supplements. On the contrary, the body weight of the untreated hyperglycemic mice (negative control group) was lost significantly $(P<0.05)$, which could be attributable to the physiological disorder in the diabetic mice as a result of the loss of amino acids and inaccessibility of carbohydrates as an energy source.

3.3. Blood Glucose Level. As shown in Table 2, the blood glucose level of the fastened mice indicates that the dose of the microencapsulated product had considerable effects on blood glucose level reduction. The negative control group, which were STZ-induced untreated mice, attended as diabetic mice whose blood glucose level was kept rising as compared to the normal control group. In addition, two of them were dead (the first one on the 12th and second on the 16 th day). There was a significant reduction of the blood glucose level after the diabetic mice were treated by the microencapsulated product and standard drug, although the blood glucose level was not returned back to normal level in 21 days. Thereafter, on the 21st day, the blood glucose level reduction was not different significantly at different doses. The same trends were shown for ethanol extract of M. stenopetala leaves in alloxan-induced diabetic mice [6] and STZ-induced diabetic rat [5].

Daily oral administration of microencapsulated product from $M$. stenopetala leaves extract had shown a significant reduction of the blood glucose level. Moreover, a significant prevention action on the blood glucose level increment was also shown when it was compared to the untreated diabetic mice. The standard drug (glibenclamide, $5 \mathrm{mg} / \mathrm{kg} /$ day) reduced the blood glucose level significantly $(P<0.05)$ when it was compared to the microencapsulated product. Glibenclamide is an antihyperglycemic drug, which results in the increment of intracellular calcium in the $\beta$-cell, which leads to stimulating for the release of insulin [24]. The result of microencapsulated product is in agreement with the report of Toma et al. [5]. On the contrary, Nardos et al. [6] found out that the extract reduced the blood glucose level higher than the standard drug.

The effectiveness in the reduction of the blood glucose level in the mice was a dose-dependent manner. Lower blood glucose levels were observed in the middle and higher dose level as indicated in Table 2. Furthermore, the daily oral administration of the highest dose of the microencapsulate $(1000 \mathrm{mg} / \mathrm{kg})$ reduced the blood glucose level comparable to that of glibenclamide on the 14th day of treatment (Table 2). 
TABLE 3: Vasodilation effect of the microencapsulated bioactive product from $M$. stenopetala leaves extract on the guinea pig thoracic aorta.

\begin{tabular}{lcc}
\hline Concentration $(\mathrm{mg} / \mathrm{mL})$ & \multicolumn{2}{c}{ Relaxation of the precontracted aorta } \\
& Extract & $\begin{array}{c}\text { Encapsulated product } \\
\text { Enc }\end{array}$ \\
\hline 2.5 & $10.00 \pm 1.08^{\mathrm{e}}$ & $4.50 \pm 0.77^{\mathrm{g}}$ \\
5 & $26.27 \pm 1.95^{\mathrm{d}}$ & $8.00 \pm 0.55^{\mathrm{f}}$ \\
10 & $53.03 \pm 2.45^{\mathrm{c}}$ & $14.33 \pm 1.03^{\mathrm{e}}$ \\
20 & $66.53 \pm 1.73^{\mathrm{b}}$ & $24.67 \pm 0.82^{\mathrm{d}}$ \\
40 & $99.13 \pm 2.02^{\mathrm{a}}$ & $38.50 \pm 1.97^{\mathrm{c}}$ \\
80 & - & $64.83 \pm 1.83^{\mathrm{b}}$ \\
160 & - & $74.17 \pm 2.04^{\mathrm{a}}$ \\
\hline
\end{tabular}

Superscripted letters in the column indicate the presence of the significant differences $(P<0.05)$ among the values which showed different concentrations of the samples.

This is due to the increase of the active compounds at a higher dose, which may in turn elevate the antioxidant activity of the microencapsulates. Kim [25] described that high methoxyl pectin contributes to decreasing the rate of glucose absorption due to its viscous nature. The increment of the concentration of the coating material also improves the lowering of the blood glucose level. The same trend was also reported for $M$. stenopetala leaves extract [5,6] and Sasa borealis extract [26]. The ethanolic extract of Zygophyllum album at high dose also resulted in a significant reduction of the blood glucose level in STZ-induced diabetic mice [27]. This probable action of the indicated activity might be attributed to the activation of protein kinase (AMPK) and enhancement of insulin signaling by the active compounds [26]. In addition, the decrease in the blood glucose level in animals might be related to the inhibition of glycogenolysis as proposed by increased liver glycogen [27].

3.4. Vasodilator Activity. The cardiovascular disorder is among the major causes of morbidity and mortality that contributes to a strong public burden on treatment and therapeutic management [28]. Vasodilation is the relaxation of the smooth muscle of blood vessels, which results in normal blood pressure. Nitric oxide is one of the most important vasodilators or endothelium-derived relaxing factors [29]. Ferreira et al. [30] found that the relaxation of the contracted aortic strip was due to the release of nitric oxide when it was treated by Hancornia speciosa extract. Similar result was also reported for Viscum album extract [31]. This shows that phytochemical constituents of the plant extracts may increase the release of nitric oxide; consequently, the vasodilation properties of nitric oxide are improved.

On the other hand, when the smooth muscle is being contracted, it results in increased blood pressure [29]. The results are shown in Table 3; the unencapsulated extract had significantly $(P<0.05)$ higher relaxation against $\mathrm{KCl}$-induced contraction of the guinea pig thoracic aorta compared to the microencapsulated product. The high relaxation (99.13\%) was found from the unencapsulated extract at the concentration of $40 \mathrm{mg} / \mathrm{mL}$. Microencapsulated product gave the maximum relaxation of $74.17 \%$ at the concentration of $160 \mathrm{mg} / \mathrm{mL}$ (Table 3). This is probably due to the variation in the concentration of the active compounds and effects of processing temperature and coating materials. Even if the pure extract had a more relaxing effect, the microencapsulated product has also shown its vasodilation effect in a dose-dependent manner.

3.5. Diuretic Activity. Diuretics also produce antihypertensive effect and have clinical application [32]. Diuretics increase the urinary sodium excretion, thereby reducing the plasma volume, which in turn lower the blood pressure, extracellular fluid volume, and cardiac output [33], though the mechanism of action of the diuretics was not known exactly.

3.5.1. Urine Output. The effect of microencapsulated product of $M$. stenopetala leaves extract on the urine output is shown in Table 4. Accordingly, the urine output of the rats treated with the microencapsulated product was considerably higher when compared to the normal control group (the group treated with normal saline solution). This showed that the microencapsulated product of $M$. stenopetala leaves extract could increase urine excretion.

The urine output was increased with increase in time until $8 \mathrm{~h}$. The urine output of rats treated with the standard drug (furosemide) was significantly higher than the microencapsulated product at $2 \mathrm{~h}$ and $4 \mathrm{~h}$. Thereafter, the urine output of the microencapsulated product was comparably increased at $8 \mathrm{~h}$ with furosemide. This indicates that the diuresis action of the furosemide drug occurred earlier than the microencapsulated product. Roush and Sica [32] described that the duration of action of the furosemide drug is $4-5 \mathrm{~h}$. The urine output was higher when the dose of the microencapsulated product was increased. The same trend was observed as reported earlier for the $70 \%$ ethanol extract of $M$. stenopetala leaves [34] and aqueous extract of T. schimperi leaves [3].

3.5.2. Urinary Excretion. The percentage of urinary excretion from the rats treated with different doses of microencapsulated bioactive product was the highest (54 and 56\%) at the dose of 750 and $1000 \mathrm{mg} / \mathrm{kg}$ at $8 \mathrm{~h}$, respectively, whereas the lowest was found in the untreated rats along the time intervals (Table 5). On the other hand, the percentage of urinary extraction was increased with the increment of the dose of the microencapsulated product as the time is getting longer to $8 \mathrm{~h}$ (Table 5). The result was in agreement with the reports of Geleta et al. [34] and Fekadu et al. [35] for M. stenopetala leaves extract.

When the standard drug (furosemide) was considered, the high urinary excretion (23\%) was found in the first $2 \mathrm{~h}$. Thereafter, it was continued with the same trend as the microencapsulated treated rats for the rest time intervals due to the aforementioned reason (Table 5). The microencapsulate took a longer time, probably due to the time required for the release of active compounds from the coating 
TABLE 4: Urine output from the rats treated with microencapsulated product of $M$. stenopetala leaves extract.

\begin{tabular}{lcccc}
\hline Treatment & & \multicolumn{2}{c}{ Urine output $(\mathrm{mL})$} & \\
& $2 \mathrm{~h}$ & $4 \mathrm{~h}$ & $6 \mathrm{~h}$ & $8 \mathrm{~h}$ \\
\hline Dose $500 \mathrm{mg} / \mathrm{kg}$ & $1.77 \pm 0.84^{\mathrm{cBC}}$ & $3.62 \pm 1.00^{\mathrm{bAB}}$ & $5.30 \pm 1.30^{\mathrm{abAB}}$ & $6.28 \pm 1.23^{\mathrm{aAB}}$ \\
Dose $750 \mathrm{mg} / \mathrm{kg}$ & $1.72 \pm 0.55^{\mathrm{cBC}}$ & $4.70 \pm 0.82^{\mathrm{bA}}$ & $5.88 \pm 0.86^{\mathrm{abA}}$ & $6.98 \pm 0.80^{\mathrm{aA}}$ \\
Dose $1000 \mathrm{mg} / \mathrm{kg}$ & $2.07 \pm 0.48^{\mathrm{cAB}}$ & $4.80 \pm 0.60^{\mathrm{bA}}$ & $6.57 \pm 0.93^{\mathrm{aA}}$ & $7.45 \pm 0.90^{\mathrm{aA}}$ \\
Positive control & $3.06 \pm 1.03^{\mathrm{cA}}$ & $4.63 \pm 1.28^{\mathrm{bcA}}$ & $5.75 \pm 0.76^{\mathrm{abAB}}$ & $6.48 \pm 0.78^{\mathrm{aAB}}$ \\
Normal control & $0.70 \pm 0.62^{\mathrm{bC}}$ & $2.67 \pm 1.65^{\mathrm{abB}}$ & $3.90 \pm 1.70^{\mathrm{aB}}$ & $4.88 \pm 1.58^{\mathrm{aB}}$ \\
\hline
\end{tabular}

All values with different superscripted small letters in each row indicate the presence of the significant differences $(P<0.05)$ in different hours, whereas the superscripted capital letters in each column indicate the presence of significant difference at different doses and control groups.

TABle 5: Diuretic activity of the rat treated by the microencapsulated bioactive product.

\begin{tabular}{lcccccccccccc}
\hline \multirow{2}{*}{ Treatment } & \multicolumn{4}{c}{ Urinary excretion (\%) } & \multicolumn{4}{c}{ Diuretic index } & \multicolumn{4}{c}{ Diuretic activity } \\
& $2 \mathrm{~h}$ & $4 \mathrm{~h}$ & $6 \mathrm{~h}$ & $8 \mathrm{~h}$ & $2 \mathrm{~h}$ & $4 \mathrm{~h}$ & $6 \mathrm{~h}$ & $8 \mathrm{~h}$ & $2 \mathrm{~h}$ & $4 \mathrm{~h}$ & $6 \mathrm{~h}$ & $8 \mathrm{~h}$ \\
\hline Dose $500 \mathrm{mg} / \mathrm{kg}$ & 13 & 26 & 38 & 45 & 2.34 & 1.25 & 1.23 & 1.14 & 0.56 & 0.76 & 0.88 \\
Dose $750 \mathrm{mg} / \mathrm{kg}$ & 14 & 37 & 46 & 54 & 2.43 & 1.73 & 1.46 & 1.36 & 0.58 & 1.05 & 1.05 & 1.09 \\
Dose $1000 \mathrm{mg} / \mathrm{kg}$ & 15 & 35 & 48 & 56 & 2.74 & 1.63 & 1.55 & 1.42 & 0.66 & 0.99 & 1.11 & 1.14 \\
Positive control & 23 & 35 & 44 & 49 & 4.17 & 1.65 & 1.40 & 1.24 & 1 & 1 & 1 & 1 \\
Normal control & 6 & 21 & 32 & 39 & 1 & 1 & 1 & 1 & - & - & - \\
\hline
\end{tabular}

TABLE 6: Electrolyte extraction in the treated rats using the microencapsulated bioactive product.

\begin{tabular}{|c|c|c|c|c|c|c|c|c|c|}
\hline \multirow{2}{*}{ Treatment } & \multicolumn{3}{|c|}{ Excreted electrolytes $(\mathrm{mmol} / \mathrm{L})$} & \multirow{2}{*}{$\begin{array}{c}\text { Natriuretic } \\
\text { activity } \\
\mathrm{Na}^{+} / \mathrm{K}^{+}\end{array}$} & \multirow{2}{*}{$\begin{array}{l}\text { Saluretic } \\
\text { activity } \\
\mathrm{Na}^{+}+\mathrm{Cl}^{-}\end{array}$} & \multirow{2}{*}{$\begin{array}{c}\text { Carbonic } \\
\text { anhydrase } \\
\text { inhibition } \\
\mathrm{Cl}^{-} /\left(\mathrm{Na}^{+}+\mathrm{K}^{+}\right)\end{array}$} & \multicolumn{3}{|c|}{ Saluretic index } \\
\hline & $\mathrm{Na}^{+}$ & $\mathrm{K}^{+}$ & $\mathrm{Cl}^{-}$ & & & & $\mathrm{Na}^{+}$ & $\mathrm{K}^{+}$ & $\mathrm{Cl}^{-}$ \\
\hline $\begin{array}{l}\text { Dose } \\
500 \mathrm{mg} / \mathrm{kg}\end{array}$ & $137.83 \pm 14.82^{\mathrm{bc}}$ & $79.73 \pm 3.36^{\mathrm{bc}}$ & $166.67 \pm 14.35^{\mathrm{ab}}$ & $1.73 \pm 0.38^{\mathrm{a}}$ & $304.50 \pm 29.13^{\mathrm{ab}}$ & $0.76 \pm 0.04^{\mathrm{a}}$ & 1.52 & 1.20 & 1.34 \\
\hline $\begin{array}{l}\text { Dose } \\
750 \mathrm{mg} / \mathrm{kg}\end{array}$ & $180.50 \pm 9.40^{\mathrm{ab}}$ & $104.15 \pm 8.75^{\mathrm{ab}}$ & $245.35 \pm 21.89^{\mathrm{a}}$ & $1.76 \pm 0.20^{\mathrm{a}}$ & $425.85 \pm 30.76^{\mathrm{a}}$ & $0.86 \pm 0.08^{\mathrm{a}}$ & 1.99 & 1.57 & 1.97 \\
\hline $\begin{array}{l}\text { Dose } \\
1000 \mathrm{mg} / \mathrm{kg}\end{array}$ & $187.33 \pm 15.33^{\mathrm{ab}}$ & $103.32 \pm 8.32^{\mathrm{ab}}$ & $243.00 \pm 31.92^{\mathrm{a}}$ & $1.82 \pm 0.19^{\mathrm{a}}$ & $430.33 \pm 46.76^{\mathrm{a}}$ & $0.82 \pm 0.12^{\mathrm{a}}$ & 2.06 & 1.56 & 1.96 \\
\hline $\begin{array}{l}\text { Positive } \\
\text { control }\end{array}$ & $191.00 \pm 13.81^{\mathrm{a}}$ & $113.62 \pm 9.19^{\mathrm{a}}$ & $253.37 \pm 27.23^{\mathrm{a}}$ & $1.73 \pm 0.38^{\mathrm{a}}$ & $444.37 \pm 46.76^{\mathrm{a}}$ & $0.82 \pm 0.13^{\mathrm{a}}$ & 2.10 & 1.72 & 2.04 \\
\hline $\begin{array}{l}\text { Normal } \\
\text { control }\end{array}$ & $90.83 \pm 5.07^{\mathrm{c}}$ & $66.25 \pm 4.97^{\mathrm{c}}$ & $124.28 \pm 7.16^{\mathrm{b}}$ & $1.42 \pm 0.40^{\mathrm{a}}$ & $215.12 \pm 11.80^{\mathrm{b}}$ & $0.79 \pm 0.06^{\mathrm{a}}$ & 1 & 1 & 1 \\
\hline
\end{tabular}

All values indicated in different superscript letters in each column indicate the presence of significant differences $(P<0.05)$ in the dose of the microencapsulated product and control groups.

material. The values of the diuretic index and diuretic activity showed the same trends with the urinary excretion (Table 5). The diuretic activity depended on the dose of the microencapsulated bioactive product. As the dose was increased, the diuretic activity was higher. The results showed that microencapsulated product of $M$. stenopetala leaves extract has a significant diuretic activity. Consequently, this microencapsulated product may be used to minimize the abnormal accumulation of fluid. The diuretics are the most commonly prescribed agents for the management of hypertension [32].

3.5.3. Electrolyte Concentration. The microencapsulated product of $M$. stenopetala leaves extract had a significant $(P<0.05)$ effect on the excretion of $\mathrm{Na}^{+}, \mathrm{K}^{+}$, and $\mathrm{Cl}^{-}$ion (Table 6). A high electrolyte excretion was observed in furosemide-provided rats followed by the microencapsulate- treated rats at the doses of 1000 and $750 \mathrm{mg} / \mathrm{kg}$, respectively. The lowest electrolyte excretion was observed for the control group (untreated rats). The highest dose of the microencapsulated product had shown significant electrolyte excretion. The T. schimperi extract also showed that the electrolyte extraction increased as the dose was increased [3]. This experimental data showed that the microencapsulated product has a role in antihypertensive activity. This effect may have advantages in the case of salt-sensitive hypertension due to the excretion of sodium. The removal of sodium may lead to a drop in systolic blood pressure of $10 \mathrm{~mm} \mathrm{Hg}$ or more [32].

Moreover, the natriuretic, saluretic, and carbon anhydrase inhibition activities were not significantly $(P<0.05)$ different at different doses of the microencapsulated product with the exception of the saluretic activity at which a significant difference was found at lower doses $(500 \mathrm{mg} / \mathrm{kg})$ of the microencapsulated product. The removal of these 
electrolytes in the body may lead to the minimization of the cardiac work by reducing the amount of plasma, thereby leading to the return of the venous to the heart [34].

The common feature of diuretics is their natriuretic action, which leads to a decrease in total body sodium [36]. The observation was made in this study that the maximum value of natriuretic activity was 1.82 , which was found from the administration of a dose of $1000 \mathrm{mg} / \mathrm{kg}$ microencapsulated product. This indicated a favorable natriuretic effect. The natriuretic activity was considered to be favorable when the value is greater than or equal to two [36]. When the value for natriuretic activity is more than ten, it is determined to have potassium sparing effect [22]. Therefore, natriuretic activity value of the treatment group indicates favorable potassium sparing although there is a tendency for excretion of potassium.

The carbonic anhydrase inhibition values of the microencapsulated bioactive product are in the range of 0.76 to 0.86 (Table 6). Carbonic anhydrase inhibitor is used to increase the urinary excretion of the bicarbonate [36]. Carbonic anhydrase inhibition can be excluded if the ratio is between 0.8 and 1 [22]. All the values in the current study were in this range except the microencapsulate at dose of $500 \mathrm{mg} / \mathrm{kg}$. Thus, the diuretic activity of the microencapsulated product did not possess carbonic anhydrase inhibition action. The diuretic activity is claimed to be effective as the carbonic anhydrase inhibition ratio is going to be decreased $[22,36]$.

\section{Conclusions}

The microencapsulated product from $M$. stenopetala leaves extract is shown to be safe as determined in the acute toxicity study. The microencapsulated bioactive product possessed significant vasodilator (up to $74.17 \%$ of relaxation) and diuretic (up to $56 \%$ of urinary excretion) activities. The blood glucose levels of the STZ-induced diabetic mice were significantly reduced when the microencapsulated product of $M$. stenopetala leaves extract was administered at the doses of 500, 750, and $1000 \mathrm{mg} / \mathrm{kg}$. The vasodilator, increased urinary excretion, and saluretic effects are indicative of the antihypertensive effect of the microencapsulated bioactive product of M. stenopetala leaves extract. Therefore, the microencapsulated product may be considered as a potential nutraceutical for prediabetic and prehypertensive treatments. Further study, however, needs to be undertaken to elucidate the possible mechanism of actions on the antihyperglycemic, vasodilator, and diuretic activities of the microencapsulated product.

\section{Data Availability}

All the data generated and analyzed during this study are included in this paper.

\section{Conflicts of Interest}

The authors declare that they have no conflicts of interest.

\section{Acknowledgments}

The authors would like to acknowledge Addis Ababa University and Ambo University for their financial support. The authors would also like to thank Traditional and Modern Medicine Research Directorate, Ethiopian Public Health Institute, for their laboratory facilities.

\section{References}

[1] N. Debelo, M. Afework, A. Debella, W. Ergete, and B. Geleta, "Histopathological and biochemical assessment of chronic oral administration of aqueous leaf extract of Thymus serrulatus in mice," Journal of Clinical Experiment Pathology, vol. 5, no. 258, pp. 2161-2181, 2015.

[2] B. Geleta, E. Makonnen, and A. Debella, "Toxicological evaluations of the crude extracts and fractions of Moringa stenopetala leaves in liver and kidney of rats," Journal of Cytology and Histology, vol. 7, no. 383, Article ID 1000383, 2016.

[3] H. Haji, E. Makonnen, A. Debella, and B. Geleta, "Evaluation of diuretic and antihypertensive activity of leaf extracts of Thymus schimperi in rats," British Journal of Pharmacology and Toxicology, vol. 7, no. 1, pp. 1-8, 2016.

[4] B. Geleta, E. Makonnen, A. Debella, and A. Tadele, "In vivo antihypertensive and antihyperlipidemic effects of the crude extracts and fractions of Moringa stenopetala (Baker f.) Cufod. leaves in rats," Frontiers in Pharmacology, vol. 7, no. 97, Article ID 103389, 2016.

[5] A. Toma, E. Makonnen, Y. Mekonnen, A. Debella, and S. Adisakwattana, "Antidiabetic activities of aqueous ethanol and n-butanol fraction of Moringa stenopetala leaves in streptozotocin-induced diabetic rats," BMC Complementary and Alternative Medicine, vol. 15, no. 1, Article ID 1507790, 2015.

[6] A. Nardos, E. Makonnen, and A. Debella, "Effects of crude extracts and fractions of Moringa stenopetala (Baker f) Cufodontis leaves in normoglycemic and alloxan-induced diabetic mice," African Journal of Pharmacy and Pharmacology, vol. 5, no. 20, pp. 2220-2225, 2011.

[7] A. R. Verma, M. Vijayakumar, C. S. Mathela, and C. V. Rao, "In vitro and in vivo antioxidant properties of different fractions of Moringa oleifera leaves," Food and Chemical Toxicology, vol. 47, no. 9, pp. 2196-2201, 2009.

[8] A. Musa, P. Vata, and A. Debella, "Acute toxicity studies of butanol fraction of leaves of Moringa stenopetala in rats," Asian Pacific Journal of Health Science, vol. 2, no. 2, pp. 160-164, 2015.

[9] D. W. Dadi, S. A. Emire, A. Debella, and F. Teka, "Influences of different drying methods and extraction solvents on total phenolic and flavonoids, and antioxidant capacity of Moringa stenopetala leaves," Journal of Pharmacognosy and Phytochemistry, vol. 7, no. 1, pp. 962-967, 2018.

[10] S. Habtemariam, "Investigation into the antioxidant and antidiabetic potential of Moringa stenopetala: identification of the active principles," Natural Product Communications, vol. 10, no. 3, pp. 475-478, 2015.

[11] S. Habtemariam and G. Varghese, "Extractability of rutin in herbal tea preparations of Moringa stenopetala leaves," Beverages, vol. 1, no. 3, pp. 169-182, 2015.

[12] B. Vongsak, P. Sithisarn, S. Mangmool, S. Thongpraditchote, Y. Wongkrajang, and W. Gritsanapan, "Maximizing total phenolics, total flavonoids contents and antioxidant activity of Moringa oleifera leaf extract by the appropriate extraction 
method," Industrial Crops and Products, vol. 44, pp. 566-571, 2013.

[13] P. Chumark, P. Khunawat, Y. Sanvarinda et al., "The in vitro and ex vivo antioxidant properties, hypolipidaemic and antiatherosclerotic activities of water extract of Moringa oleifera Lam. leaves," Journal of Ethnopharmacology, vol. 116, no. 3, pp. 439-446, 2008.

[14] C. Abuye, K. Urga, H. Knapp et al., "A compositional study of Moringa stenopetala leaves," East African Medical Journal, vol. 80 , no. 5, pp. 247-252, 2003.

[15] J. Shi, Functional Food Ingredients and Nutraceuticals: Processing Technologies, CRC Press, Boca Raton, FL, USA, 2006.

[16] B. Vongsak, P. Sithisarn, and W. Gritsanapan, "Bioactive contents and free radical scavenging activity of Moringa oleifera leaf extract under different storage conditions," Industrial Crops and Products, vol. 49, pp. 419-421, 2013.

[17] N. J. Zuidam and E. Shimoni, Overview of Microencapsulates for Use in Food Products or Processes and Methods to Make Them, Springer, New York, NY, USA, 2010.

[18] L. M. Sagis, Microencapsulation and Microspheres for Food Applications, Academic Press, New York, NY, USA, 2015.

[19] D. W. Dadi, S. A. Emire, A. D. Hago, and J. B. Eun, "Development of microencapsulated bioactive product from M. stenopetala leaves extract by optimizing spray drying process parameters," Annals. Food Science and Technology, vol. 20, no. 2, pp. 191-206, 2019.

[20] National Research Council, Guideline for the Care and Use of Laboratory Animals, National Academy Press, Washington, DC, USA, 2011.

[21] B. L. Furman, "Streptozotocin-induced diabetic models in mice and rats," Current Protocols in Pharmacology, vol. 70, no. 1, pp. 5.47.1-5.47.20, 2015.

[22] H. G. Vogel, Drug Discovery and Evaluation: Pharmacological Assays, Springer, New York, NY, USA, 2002.

[23] A. J. King, "The use of animal models in diabetes research," British Journal of Pharmacology, vol. 166, no. 3, pp. 877-894, 2012.

[24] X. Serrano-Martín, G. Payares, and A. Mendoza-León, "Glibenclamide, a blocker of K+ATP channels, shows antileishmanial activity in experimental murine cutaneous leishmaniasis," Antimicrobial Agents and Chemotherapy, vol. 50, no. 12, pp. 4214-4216, 2006.

[25] M. Kim, "High-methoxyl pectin has greater enhancing effect on glucose uptake in intestinal perfused rats," Nutrition, vol. 21, no. 3, pp. 372-377, 2005.

[26] J. S. Nam, H. J. Chung, M. K. Jang et al., "Sasa borealisextract exerts an antidiabetic effect via activation of the AMP-activated protein kinase," Nutrition Research and Practice, vol. 7, no. 1, pp. 15-21, 2013.

[27] J. E. Ghoul, N. A. Boughattas, and M. Ben-Attia, "Antihyperglycemic and antihyperlipidemic activities of ethanolic extract of Zygophyllum albumin streptozotocin-induced diabetic mice," Toxicology and Industrial Health, vol. 29, no. 1, pp. 43-51, 2013.

[28] A. S. Go, D. Mozaffarian, V. L. Roger et al., "Executive summary: heart disease and stroke statistics, a report from the American Heart Association," Circulation, vol. 129, no. 3, pp. 399-410, 2014.

[29] D. Versari, E. Daghini, A. Virdis, L. Ghiadoni, and S. Taddei, "Endothelium-dependent contractions and endothelial dysfunction in human hypertension," British Journal of Pharmacology, vol. 157, no. 4, pp. 527-536, 2009.

[30] H. C. Ferreira, C. P. Serra, V. S. Lemos, F. C. Braga, and S. F. Cortes, "Nitric oxide-dependent vasodilatation by ethanolic extract of Hancornia speciosa via phosphatidylinositol 3-kinase," Journal of Ethnopharmacology, vol. 109, no. 1, pp. 161-164, 2007.

[31] F. A. Tenorio, L. del Valle, A. González, and G. Pastelín, "Vasodilator activity of the aqueous extract of Viscum album," Fitoterapia, vol. 76, no. 2, pp. 204-209, 2005.

[32] G. C. Roush and D. A. Sica, "Diuretics for hypertension: a review and update," American Journal of Hypertension, vol. 29, no. 10, pp. 1130-1137, 2016.

[33] S. U. Shah, S. Anjum, and W. Littler, "Use of diuretics in cardiovascular disease: (2) hypertension," Postgraduate Medical Journal, vol. 80, no. 943, pp. 271-276, 2004.

[34] B. Geleta, M. Eyasu, N. Fekadu, A. Debella, and F. Challa, "Evaluation of diuretic activity of hydro-ethanolic extract of Moringa stenopetala leaves in Swiss albino mice," Clinical and Experimental Pharmacoloy, vol. 5, no. 5, Article ID 000190, 2015.

[35] N. Fekadu, H. Basha, A. Meresa, S. Degu, B. Girma, and B. Geleta, "Diuretic activity of the aqueous crude extract and hot tea infusion of Moringa stenopetala (Baker f.) Cufod. leaves in rats," Journal of Experimental Pharmacology, vol. Volume 9, pp. 73-80, 2017.

[36] S. E. Hart, Diuretic and Saluretic Activity: Drug Discovery and Evaluation: Pharmacological Assays, Springer, Cham, Switzerland, 2015. 